\title{
危険度認識のドライバ一間の不一致度と交通事故の発生率* Variance of Drivers' Risk Recognitions and Occurrence of Traffic Accidents*
}

\author{
西村智明**・ハック=M=シャーミム***・奥村 誠****・塚井誠人***** \\ By Tomoaki NISHIMURA** · Shamim M. HAQUE*** • Makoto OKUMURA**** • Makoto TSUKAI*****
}

\section{1. はじめに}

交通事故の防止は, 交通工学に科せられた重要なテー マであり, 交通事故の発生メカニズムの解明に向けて 様々な研究が実施され ${ }^{1)}$, 近年ではドライバーの危険度 の認識に関する研究も行われるようになってきた. 森地 $ら^{2)}$, 古池ら ${ }^{3)}$ の研究では, 危険度認識の形成には道路 構造や視認性, 交通流特性が影響することが報告されて いる. 危険度認識と交通事故件数との間の関係として, 「地点の持つ危険度とドライバーの危険度認識の乘離が 事故発生に影響を与える」という仮説を立てることがで きよう.しかしこの仮説は車両単独事故を説明するに過 ぎず，事故のメカニズムを説明できるものではない，交 通事故の約 8 割を占めている車両相互事故は, 各ドライ バーで地点に対する危険度認識が異なるにもかかわらず, ドライバーは地点に対する自らの危険度認識を元に相手 の挙動を予測し, 行動せざるを得ず, その結果予測と実 際の相手の挙動に食い違いを生じるために起こると考え られる.

したがって本研究では，「同じ地点に対する危険度認 識のドライバー間の不一致度が高いほど車両相互事故が 多く発生する」という仮説を確認することを目的とする. 対象地域は，広島県の中でも交通事故数が増加している 東広島市とする. 同市では広島大学, 近畿大学の移転に より若年齢ドライバーの急増, 自動車保有数の急増が見 られる. また大学機関, 空港の移転にともない人口が増 加し, 商業活動に関連する事業車ドライバーの活動も盛 んになっている. そこで，学生ドライバー，業務ドライ バー，及び一般の市民にアンケートを行い，日常利用経 路上で危険と感じる地点の調査を行った. これから各地 点における危険度認識のドライバ一間の不一致度を表す 指標を定義し，1996年から1999年の間の事故発生件数と の関連性を考察する.

\footnotetext{
*キーワーズ : 交通安全, 意識調査分析, GIS

** 学生員 広島大学大学院工学研究科

*** 非会員, Mr. Eng 広島大学大学院工学研究科

**** 正員, 博(工) 広島大学大学院工学研究科

***** 正員, 修(工) 広島大学大学院工学研究科
}

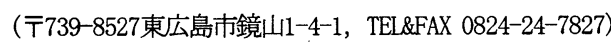

\section{2. 本研究の特徵}

\section{（1）交通事故危険度に関する研究の経緯1)}

交通事故件数に基づく危険地点の抽出や，交通状況， 道路構造, 沿道状況等の事故関連要因を説明変数とし事 故件数や事故率を目的変数とする多変量解析モデルの作 成が一段落した1980年ごろから, 道路の物理構造や交通 特性のみでは説明できないより細かな事故特性を説明す るために，ドライバーの注視行動の計測や危険意識を考 慮するミクロな立場からの研究が始められた。 また， 「ヒヤリ，ハットマップ」の作成により，ニアミス事象 をとらえて交通事故という低確率な現象をより安定的に 分析する試みもなされており ${ }^{4)}$, ヒヤリハットマップの 作成作業自体が参加者の安全意識を高めると共に, 参加 者の認識を実際の危険性との差異を埋める効果があると 期待されている.

これらの研究では，交通事故という確率的デ一タを補 完するものとして意識指標を取りあげている. 意識のド ライバー間の不一致に着目した研究としては, 喜多らに よる合流部における減速・避走に関する一連のゲーム論 的研究が挙げられるものの バラツキを統計的にとらえようとする研究は見られない.

\section{(2) 本研究の視点}

長年に亘る交通安全対策により，「誰が見ても危ない と感じるような地点」についての対策はかなりの程度進 んだと考えられる. また，そのような場所では危険であ るという認識が定着し，ほとんどのドライバーが注意深 く運転することから，ドライバー間で危険度認識に不一 致は生じにくく，かえって実際に発生する事故は少ない と考えられる. 一方, 見通しや幅員などの条件が良く, 誰にとっても問題のない地点でもドライバー間で危険度 認識に不一致は生じにくく，事故が起こりにくいのは当 然である. 従って危険性が少数のドライバーにしか認識 されておらず，危険度認識にドライバ一間で不一致が生 じるような地点では，相手車両の予測に反する挙動に対 処できずに交通事故が発生している可能性がある（図一 1). 本研究では, アンケートにより同じ地点に対する 危険度認識のドライバー間の不一致度を測定し，それが 交通事故の発生要因になっているという仮説を立て, そ れを確認する. 


\section{3. 使用データの概要}

\section{(1) アンケート調査}

アンケートは運転経験，技能の特性の異なる学生・業 務・一般の 3 グループのドライバーに対して行った（表 -1）. 調査では東広島市の幹線道路ネットワークを提 示して, 危険地点とその進入方向, 日常利用経路の記入 を求め (図一2)，指摘のあった地点ごとに，設定した 項目（表一2）の中から該当する危険理由を回答させた.

アンケートの回答結果より, この地域ではネットワー ク上の149力所の交差点のうち, 44力所が危険地点とし て指摘されている. 地点 $i$ を危険地点として指摘した回 答者数 $M_{i}$ を, その地点を日常経路として利用している 回答者数 $N_{i}$ て除した数值を, 「危険地点指摘率」 $D_{i}=$ $M_{i} / N_{i}$ と定義する. また, 地点 $i$ の危険理由 $j$ の指摘数 $M_{i j}$ を $N_{i}$ て除した数值を, 「危険理由指摘率」 $D_{i j}=M_{i j}$ $/ N_{i}$ と定義する. 表一 2 には149地点についての危険地点 指摘率と危険理由指摘率の平均値を示している.

これより，危険理由としては，「b. 見通しが悪いりや 「d. 信号がない，少ない，「f. 自動車の交通量が多

いなどの項目の指摘率が高いことがわかる.

\section{(2) その他のデータ}

交通事故デー夕は，西条署が住宅地図上に人身事故の 発生地点をプロットした交通事故分析図を借用し，GIS 上に入力した. 今回の分析で用いる各交差点での事故発 生件数は, 着目している車両相互事故が集中する交差点

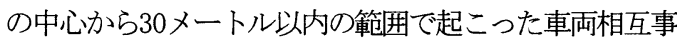
故の数とした. アンケートでは危険地点を進入方向別に 指摘させたが，交通事故データが方向別のデータとして 得られなかったため, 分析単位は方向別とはせず，交差 点ごととした. また，アンケートにより危険地点として 指摘された箇所について, 車種別交通量と幅員や車線数 などの道路構造を実測した.

図一ろは, 東広島市の道路ネットワーク上の149地点に ついて，危険地点指摘率と，1996年から1999年までに実 際に発生した車両相互事故件数を散布図で表わしている (危険地点指摘率が0のプロットは複数の地点のものが 重なっているため, プロット数は149より少ない）。こ れより, 危険地点指摘率が高いほど交通事故発生件数が

追突事故

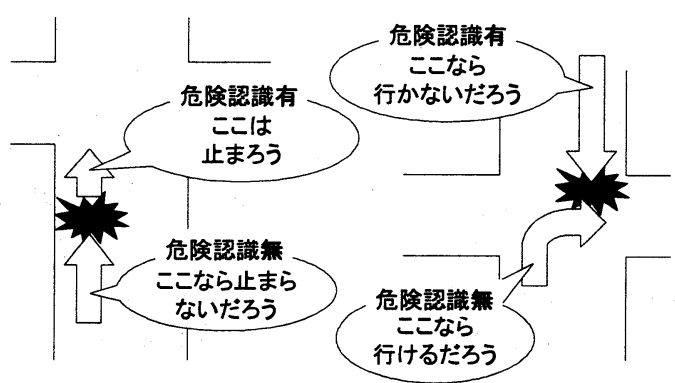

図ー1 認識の逴いで発生すると考えられる事故の例
表ー1 アンケートの諸元

\begin{tabular}{llllll}
\hline & 配布・回収配布枚数 配布対象 回収数回収率 \\
\hline 学生 (広島大学) & 直接・直接 & 100 & 2 クラス & 61 & $61 \%$ \\
学生 (近畿大学) & 直接・直接 & 120 & & 92 & $77 \%$ \\
業務 & 郵送・郵送 & 444 & 222 事業所 & 56 & $13 \%$ \\
一般 (幼稚園児の家族) & 間接・間接 & 362 & 1幼稚園 & 93 & $26 \%$ \\
\hline 全体 & & 1026 & & 302 & $29 \%$ \\
\hline
\end{tabular}

$※ 2001$ 年7月実施

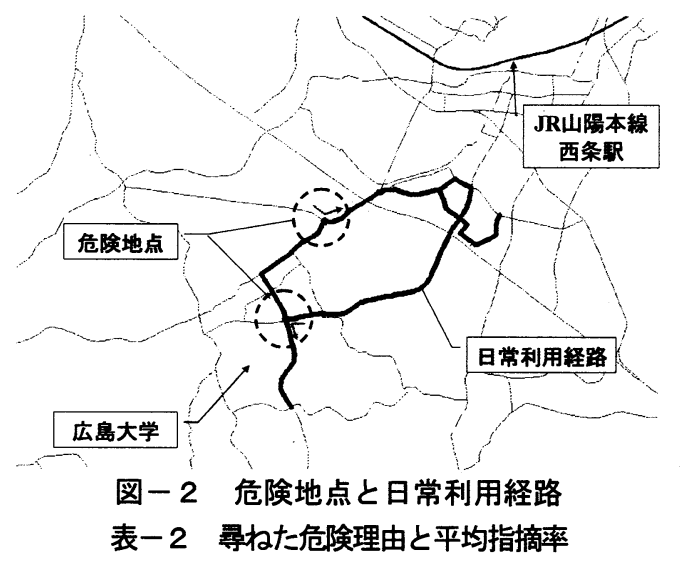

\begin{tabular}{|c|c|}
\hline 項目 & 平均指摘率 \\
\hline \multicolumn{2}{|l|}{ 危険理由指摘率 $D$} \\
\hline a ：道路のカーブ、勾配がきつい & $0.82 \%$ \\
\hline b ：見通しが悪い & $2.42 \%$ \\
\hline : 道路の幅が狭い & $0.66 \%$ \\
\hline : 信号がない・少ない & $1.89 \%$ \\
\hline e ：照明が不十分で暗い & $0.19 \%$ \\
\hline f ：自動車の交通量が多い & $1.88 \%$ \\
\hline : 車種が入り混じっている & $0.62 \%$ \\
\hline h ：スピードを出しすぎる車が多い & $1.63 \%$ \\
\hline : 交差道路からの飛び出しが多い & $1.70 \%$ \\
\hline : 沿道の商店等への出入りが多い & $0.36 \%$ \\
\hline ：車道を通る二輪車・自転車が多い & $0.43 \%$ \\
\hline 1 : 歩道がない & $0.34 \%$ \\
\hline m : 歩行者の横断が多い & $0.76 \%$ \\
\hline n ：交差点の構造が悪い & $0.49 \%$ \\
\hline : 信号の現示パターンが悪い & $0.42 \%$ \\
\hline p ：凍結が起こる & $0.00 \%$ \\
\hline 危険地点指摘率 $D_{i}$ & $4.60 \%$ \\
\hline
\end{tabular}

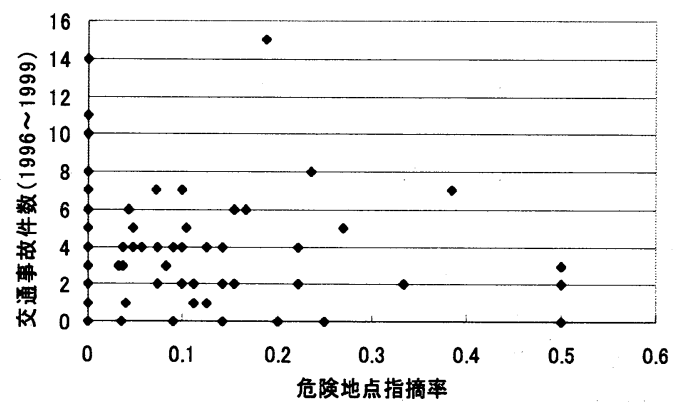

図一3 危険地点指摘率と車両相互事故発生件数 
少ないという単純な傾向は見られず, 旧来の仮説と本研 究の仮説のどちらが正しいかを直観的に確認することは できない．また，交通事故の発生が確率的であるため, 4年間の発生件数が0である地点も少なくない.

\section{4. 交通事故発生のモデル (1) ポアソン事故発生モデル}

交通事故の発生が稀現象であるとすれば, 各地点 $i$ での 年間発生件数 $x_{i}$ はポアソン分布に従うと考えられる. そこで年間平均発生率 $\lambda_{i}$ を， $\lambda_{i}>0$ となることを保証す るために対数をとり, 地点ごとの説明変数 $Z_{i k}$ の線形関 数とおけば, 次のような尤度関数, 対数尤度関数が構成 できる.

$$
\begin{aligned}
& \log \lambda_{i}=\sum_{k} Z_{i k} \beta_{k} \\
& L=\prod_{i} \frac{\lambda_{i}^{x_{i}}}{x_{i} !} \exp \left(-\lambda_{i}\right)
\end{aligned}
$$

$$
\log L=\sum_{i}\left\{x_{i} \log \lambda_{i}-\lambda_{i}-\log \left(x_{i} !\right)\right\}
$$

最尤法により, 対数尤度関数を最大にするパラメータ $\beta_{i k}$ を求めることができる.

\section{(2) 対数トービットモデル}

上記のモデルは理論に忠実であるものの，尤度関数の 非線形性が強いために局所最適解しか得られない危険性 が高い. また，事故件数が小さい領域ではポアソン分布 の最大值はほぼ $\lambda_{i}$ に等しい場所に現れることを考えれば, 実際の観測数を直接回帰してもほぼ同様の結果が得られ ると考えられる. この時, 年間発生件数 $x_{i}$ が正数であ ることから，その対数を回帰することとする. また，0 回という観測值は, 1 回未満の発生に対応すると考える と，以下のようなトービットモデルで表現できることに なる.

$$
\begin{aligned}
& \log \lambda_{i}=\sum_{k} Z_{i k} \beta_{k} \\
& x_{i}= \begin{cases}0 & \left(\lambda_{i}<1\right) \\
\lambda_{i} & \left(\lambda_{i} \geq 1\right)\end{cases}
\end{aligned}
$$

対数尤度関数は以下のようになり, 最尤法によってパ ラメータ $\beta_{i k}$ と $\sigma$ を求めることができる

$$
\begin{aligned}
& \log L=\sum_{i \in\left(x_{i}=0\right)} \log \Phi\left(-\log \lambda_{i} / \sigma\right) \\
& \quad+\sum_{i \in\left(x_{i}=\lambda_{i}\right)}\left\{\log \phi\left[\left(x_{i}-\log \lambda_{i} / \sigma\right]-\log \sigma\right\}\right. \\
& \Phi \text { : 正規分布の分布関数 } \phi: \text { 正規分布の密度関数 } \\
& \sigma \text { : 正規確率変数の標準偏差 }
\end{aligned}
$$

\section{（3）危険度認識の不一致が与える影響の考慮}

いずれのモデルにおいても, 説明変数 $Z_{i k}$ として, ま
ず地点の交通量や道路構造に関する变数のみを考える (このモデルをモデルロと呼ぶ)．なお，相関が高いこ とが予想される変数の組み合わせ (交通量と幅員など) について予説明変数間の内部相関を調べたが，どれも 相関係数は低く $(<0.4)$, 深刻な重共線性は発生して いないと考えられる.

次に, 地点 $i$ を通過するドライバーの危険度認識が, アンケートにより得られた分布に一致していると仮定す る. 地点 $i$ において, 地点 $i$ を危険地点として認識して いるドライバーが認識していないドライバーと遭遇する 確率は, $2 D_{i}\left(1-D_{i}\right)$ に等しい. この時，両者は異なる認識 に基づいて互いに不整合な判断, 行動を取る可能性があ り，交通事故につながる危険性が生じる，従って年間平 均発生率の説明変数として, 各地点における認識の不一 致の強度を表す $\delta_{i}=D_{i}\left(1-D_{i}\right)$ を加えたモデルを推定する （モデル1）.

また，危険理由の中には，認識の不一致が直接車両相 互の交通事故の発生につながらないものもあり得る.し かし，ある地点に対して何らかの危険認識を持つドライ バーは，その危険理由が何であるにせよ危険を想定し， 注意して通行することが考えられるので, あるタイプの 危険度を認識しているドライバーと，全く危険度を認識 していないドライバーの遭遇を考えた認識の不一致度 $\delta_{i j}$ $=D_{i j}\left(1-D_{j}\right)$ を定義し，危険理由の指摘率を元に值を求めて モデルの説明変数に加える（モデル2）．

これら3つのモデルを比較することにより, 適合度の 改善をチェックすることとする.

\section{5. 推定結果の考察}

目的变数である事故発生件数の期間は, 不一致度, 道 路構造や交通量といった各説明変数を2001年において用 意しているため，これに近い期間に設定することが望ま しい. しかし事故が稀事象であるため, 少ない年数では 0観測が多く, モデルの適合度が下がる. よって目的変 数にとる期間を様々に変化させ推定を行った結果, 表一 3, 表一4に示すように, ポアソン事故発生モデル, 対 数トービットモデルとも，1996年から1999年の4年間の 車両相互事故の発生件数を目的変数に用いた場合の適合 度が最も高かった. よって以下では4年間のデータから 得られた結果について考察を行う。

ポアソン事故発生モデルの推定結果を表一5に, 対数 トービットモデルの推定結果を表一6に示す，パラメー 夕推定值は, 正であれば事故数の増加に寄与する要因で あることを意味する. ポアソン事故発生モデルと対数卜 ービットモデルの推定結果は類似しているが，地点の交 通量や道路構造などの説明変数の有意水準はポアソン事 故発生モデルのほうがやや高く, 事故件数のポアソン分 布への適合が高いことがわかる. 
説明変数に危険認識の不一致度を加えると，その値は 正で有意となり，危険認識の不一致度が高いほど，事故 数が増加する傾向があることがわかる．さらに危険理由 別の認識の不一致度を加えると, ポアソン事故発生モデ ルでは「交通量が多いりという危険理由の認識の不一致 度が関与している. しかし「見通しが悪いという危険 理由の認識の不一致度は，事故件数を有意に説明できな いという結果が得られた。

以上のことから，危険認識の不一致度あるいは，「交 通量が多いという危険理由の認識の不一致度のパラメ 一タが有意に正であり（モデルP1, T1, P2），認識の不一 致度を考慮することによって，交通事故発生モデルの適 合度が向上することがわかった．また，危険理由の認識 の不一致度の中には, 事故数の増加につながらないもの もあることがわかった。

本研究で用いたサンプルでは危険地点指摘率が 0.5 を超 える地点が無かったため, 危険地点指摘率D之不一致度

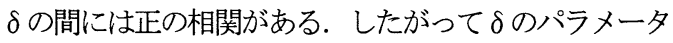
は危険地点指摘率の影響を表している可能性は否定でき ない.しかしパラメータ値は有意に正であるから，「危 険認識が高いほど事故が少ない」という旧来の仮説とは 矛盾しており, 結果の解釈ができない.

以上の結果から，「同じ地点に対する危険度認識のド ライバ一間の不一致度が大きいほど, 交通事故が多く発 生するという本研究の仮説は支持されたと結論づけられ る.

\section{6. おわりに}

本研究では, 同じ地点に対するドライバー間の危険度 認識の不一致度が大きいほど, 交通事故が多く発生する という仮説を確かめることができた. ドライバーの安全 教育の際に, 特に住区内道路のように利用するドライバ 一が限られている道路では, 認識のバラツキが大きい交 差点の存在を示して注意を喚起することで, 皆に危険認 識を持たせ, 認識の不一致が生じないようにすることが 有効であろう。なお，筆者らは別途危険度認識の形成過 程についての研究を進めている ${ }^{6}$. 本研究との統合が望 まれるところである.

今後の課題として, 交通事故発生の確率的な性 質を踏まえ, ニアミスデータを用いてモデルの信 頼性を改善することが望まれる，その他に，地点 の平均発生率を説明するための変数として, より 詳細な道路構造や周辺の土地利用のデータを加え ることが必要であろう。
表一3 ポアソン事故発生モデルの目的変数と適合度

\begin{tabular}{|c|c|c|c|}
\hline 目的変数とする & \multicolumn{3}{|c|}{ 自由度調整済尤度比 } \\
\cline { 2 - 4 } 故発生件数 & モデル P1 & モデル P2 & モデル P0 \\
\hline 1999年(1年間) & 0.41 & 0.42 & 0.40 \\
\hline 1998〜1999年(2年間) & 0.48 & 0.48 & 0.46 \\
\hline 1997〜1999年(3年間) & 0.64 & 0.64 & 0.62 \\
\hline $1996 〜 1999$ 年(4年間) & 0.76 & 0.77 & 0.75 \\
\hline
\end{tabular}

表-4 対数トービットモデルの目的変数と適合度

\begin{tabular}{|c|c|c|c|}
\hline 目的変数とする & \multicolumn{3}{|c|}{ 自由度調整済尤度比 } \\
\cline { 2 - 4 } & モデル T1 & モデル T2生件数 & モデル T0 \\
\hline 1999年(1年間) & 0.53 & - & 0.53 \\
\hline $1998 \sim 1999$ 年(2年間) & 0.69 & 0.69 & 0.67 \\
\hline $1997 \sim 1999$ 年(3年閏) & 0.80 & 0.80 & 0.79 \\
\hline $1996 \sim 1999$ 年(4年間) & 0.87 & 0.88 & 0.86 \\
\hline
\end{tabular}

\section{表一 5 ポアソン事故発生モデルの推定結果}

\begin{tabular}{|c|c|c|c|}
\hline 目的変数: 96 年 $\sim 99$ 年 & モテル P1 & モテル P2 & モデル P0 \\
\hline 説明変数 & 推定值/(t值) & 推定值/(t值) & 推定値/(t值) \\
\hline 認識の不一致度: $\delta_{\mathrm{i}}$ & $\begin{array}{l}2.8621 \text { ** } \\
(4.431)\end{array}$ & & \\
\hline $\begin{array}{l}\text { 認識の不一致度: } \delta_{i j} \\
\text { (理由:見通しが悪い) }\end{array}$ & & $\begin{array}{l}-0.1481 \\
(-0.145)\end{array}$ & \\
\hline $\begin{array}{l}\text { 認識の不一致度: } \delta_{\mathrm{ij}} \\
\text { (理由:交通量が多い) }\end{array}$ & & $\begin{array}{l}3.5046 * * \\
(3.640)\end{array}$ & \\
\hline 信号有無ダミー & $\begin{array}{l}0.0006 \\
(0.009)\end{array}$ & $\begin{array}{l}0.0005 \\
(0.009)\end{array}$ & 0.0004 \\
\hline 道路幅員 & $\begin{array}{l}0.4350 * * \\
(2.889)\end{array}$ & $\begin{array}{l}0.3914 \text { ** } \\
(2.618)\end{array}$ & $\begin{array}{l}0.3944 * * \\
(2.634)\end{array}$ \\
\hline 交通量 & $\begin{array}{l}0.9074 \text { ** } \\
(9.696)\end{array}$ & $\begin{array}{l}0.8639 * * \\
(8.627)\end{array}$ & $\begin{array}{l}0.9297 \\
(11.736)\end{array}$ \\
\hline 定数 & $\begin{array}{l}-7.7010 * * \\
(-9.281)\end{array}$ & $\begin{array}{l}-7.1961 \text { ** } \\
(-8.102)\end{array}$ & $\begin{array}{l}-7.6818 * * \\
(-10.158)\end{array}$ \\
\hline 初期尤度 & -1206.96 & -1206.96 & -1206.96 \\
\hline 最終尤度 & -316.49 & -318.48 & -323.29 \\
\hline 尤度比 & 0.74 & 0.74 & 0.73 \\
\hline 自由度調整済尤度比 & 0.76 & 0.77 & 0.75 \\
\hline \multicolumn{4}{|c|}{ 表一6 対数トービットモデルの推定結果 } \\
\hline 目的変数:96年～99年 & モデル T1 & モデル T2 & モテル T0 \\
\hline 説明変数 & 推定值/(t值) & 推定值/(t值) & 推定值/(t值) \\
\hline 認識の不一致度: $\delta_{\mathrm{i}}$ & $\begin{array}{l}5.2252 \text { ** } \\
(3.466)\end{array}$ & & \\
\hline $\begin{array}{l}\text { 認識の不一致度: } \delta_{\mathrm{ij}} \\
\text { (理由:見通しが悪い) } \\
\text { 認識の不一致度: } \delta_{\mathrm{ij}} \\
\text { (理由:交通量が多い) }\end{array}$ & & $\begin{array}{l}1.3439 \\
(0.571) \\
4.6551 \\
(1.617)\end{array}$ & \\
\hline 信号有無ダミー & $\begin{array}{l}0.0011 \\
(0.981)\end{array}$ & $\begin{array}{l}0.0010 \\
(0.893)\end{array}$ & $\begin{array}{l}0.0009 \\
(0.795)\end{array}$ \\
\hline 道路幅員 & $\begin{array}{l}0.2388 \\
(0.533)\end{array}$ & $\begin{array}{c}0.2342 \\
(0.512)\end{array}$ & $\begin{array}{l}0.2969 \\
(0.638)\end{array}$ \\
\hline 交通量 & $\begin{array}{l}1.0901 \\
(5.223)\end{array} * *$ & $\begin{array}{l}1.0129 * * \\
(4.682)\end{array}$ & $\begin{array}{l}1.0639 \\
(5.010)\end{array} * *$ \\
\hline 定数 & $\begin{array}{l}-9.3817 \text { ** } \\
(-5.576)\end{array}$ & $\begin{array}{l}-8.6459 * * \\
(-4.960)\end{array}$ & $\begin{array}{l}-9.1067 \text { ** } \\
(-5.319)\end{array}$ \\
\hline 分散 & $\begin{array}{c}1.0904 * * \\
(11.105)\end{array}$ & $\begin{array}{c}1.1163 \text { ** } \\
(11.066)\end{array}$ & $\begin{array}{l}1.1410 * * \\
(11.051)\end{array}$ \\
\hline 初期尤度 & -1001.66 & -1001.66 & -1001.66 \\
\hline 最終尤度 & -162.58 & -166.09 & -168.62 \\
\hline 尤度比 & 0.84 & 0.83 & 0.83 \\
\hline 自由度調整済尤度比 & 0.87 & 0.88 & 0.86 \\
\hline
\end{tabular}


参考文献

1）斉藤和夫 他: 交通安全研究のレビューと今後の課

題, 土木計画学研究・講演集, No16 (2), pp143-154, 1993.

2）森地茂・浜岡秀勝 : 交通事故の危険意識に関する考

察, 土木計画学研究・論文集, No12, pp. 713- 718, 1995.

3）古池弘隆 - 森本章倫 - 守谷隆志 - 白石慎重 : 認知空 間を考慮した交通事故と危険意識に関する研究, 第 37 回 土木計画学シンポジウム論文集, pp17- 22, 2001.

4）加藤哲雄 - 李偉国 - 川上洋司 - 本多義明 : 潜在事故
に着目した高齢運転者の事故特性に関する研究, 土木計 画学・論文集, No. 17, pp. 899-906, 2000.

5）喜多秀行・久保薗寛 : 低速合流時の合流挙動と潜在 危険度に関する一考察, 第 12 回交通工学研究発表会論文 集, pp. 81-84, 1992.

6）西村智明・奥村誠・ハック=M=シャーミム・塚井誠 人 : 交通事故危険度認知モデルの東広島市への適用, 第 22 回交通工学研究発表会論文集, pp. 29-32, 2002.

\section{ドライバーの危険度認識と交通事故の発生率*}

西村智明**・ハック= $\mathrm{M}=$ ・シャーミム*** ・奥村 誠****・塚井誠人***** 交通事故の約 8 割を占める車輛相互事故は，互いに異なる色険度認識を持つドライバ一が遭遇し，それぞれが自らの危 険度認識に基づいて相手の挙動を予測した結果が食い違うために起こると考えられる. 本研究では, アンケート調査に より得た結果から同じ地点に対する危険度認識のドライバ一間の不一致度を測定し，それが大きいほど交通事故が多く 発生するという仮説を立て，交通事故発生のモデルを作成することにより確認した。 その結果，交通事故発生という現 象のポアソン分布への適合性が高いこと，また危険理由の認識の不一致度の中には，事故数の増加につながらない理由 があることが明らかとなった。

\section{Variance of Drivers' Risk Recognitions and Occurrence of Traffic Accidents*}

By Tomoaki NISHIMURA** - Shamim M. HAQUE*** • Makoto OKUMURA**** - Makoto TSUKAI***** Vehicle-to-vehicle type collisions, which make up $80 \%$ of traffic accidents, are considered to be the result of nonconsistent behaviors of conflicting divers due to their differences in risk recognition about any particular spot. With this research, the hypothesis that risk recognition difference has positive effect on the accident occurrence has been proven by constructing models of a traffic accident occurrence. In addition, from results of this research, the occurrence of traffic accident highly fits to Poisson distribution, and non-agreements of risk recognition for some reasons don't have positive effect on accident occurrence. 